\title{
Population genetics of Australian white sharks reveals fine-scale spatial structure, transoceanic dispersal events and low effective population sizes
}

\author{
Dean C. Blower ${ }^{1, *}$, John M. Pandolfi ${ }^{1,2}$, Barry D. Bruce ${ }^{3}$, \\ Maria del C. Gomez-Cabrera ${ }^{1,2}$, Jennifer R. Ovenden ${ }^{4}$ \\ ${ }^{1}$ School of Biological Sciences, and ${ }^{2}$ Australian Research Council Centre of Excellence for Coral Reef Studies, \\ The University of Queensland, St Lucia, Queensland 4072, Australia \\ ${ }^{3}$ Wealth from Oceans Flagship, Commonwealth Scientific and Industrial Research Organization (CSIRO) \\ Marine and Atmospheric Research, Hobart, Tasmania 7000, Australia \\ ${ }^{4}$ Molecular Fisheries Laboratory, Queensland Government Department of Employment, \\ Economic Development and Innovation, St Lucia, Queensland 4072, Australia
}

\begin{abstract}
Despite international protection of white sharks Carcharodon carcharias, important conservation parameters such as abundance, population structure and genetic diversity are largely unknown. The tissue of 97 predominately juvenile white sharks sampled from spatially distant eastern and southwestern Australian coastlines was sequenced for the mitochondrial DNA (mtDNA) control region and genotyped with 6 nuclear-encoded microsatellite loci. MtDNA population structure was found between the eastern and southwestern coasts $\left(F_{\mathrm{ST}}=0.142, \mathrm{p}<0.0001\right)$, implying female reproductive philopatry. This concurs with recent satellite and acoustic tracking findings which suggest the sustained presence of discrete east coast nursery areas. Furthermore, population subdivision was found between the same regions with biparentally inherited microsatellite markers $\left(F_{\mathrm{ST}}=0.009, \mathrm{p}<0.05\right)$, suggesting that males may also exhibit some degree of reproductive philopatry; 5 sharks captured along the east coast had mtDNA haplotypes that resembled western Indian Ocean sharks more closely than Australian/New Zealand sharks, suggesting that transoceanic dispersal, or migration resulting in breeding, may occur sporadically. Our most robust estimate of contemporary genetic effective population size was low and close to thresholds at which adaptive potential may be lost. For a variety of reasons, these contemporary estimates were at least 1, possibly 2, orders of magnitude below our historical effective size estimates. Population decline could expose these genetically isolated populations to detrimental genetic effects. Regional Australian white shark conservation management units should be implemented until genetic population structure, size and diversity can be investigated in more detail.
\end{abstract}

KEY WORDS: Carcharodon carcharias $\cdot$ Population structure $\cdot$ Philopatry $\cdot$ Effective population size $\cdot$ Population genetics $\cdot$ Conservation $\cdot$ Nursery areas $\cdot$ Reproductive strategy

- Resale or republication not permitted without written consent of the publisher

\section{INTRODUCTION}

Understanding genetic diversity, population connectivity and trends of abundance is crucial to the development of conservation goals for vulnerable species (Reed \& Frankham 2003). However, these key properties remain largely unmeasured for the white shark Carcharodon carcharias. Many elasmobranchs (sharks, skates and rays) are susceptible to rapid population depletion, as they are slow to reach sexual maturity and have relatively low fecundity (Stevens et al. 2000, Dulvy et al. 2008). In addition, localized depletion rates may be increased by fidelity to favoured sites (Hueter et al. 2005). White sharks 
exemplify these traits (Smith et al. 1998, Bruce 2008, Dulvy et al. 2008), the species is slow to mature ( 7 to 9 yr [males]; 12 to $17 \mathrm{yr}$ [females]), has low fecundity (litter size: 2 to 12), has infrequent reproduction (every 2 to $3 \mathrm{yr}$ ), a long life-span (up to $60 \mathrm{yr}$ ) and shows indications of site-fidelity (Pardini et al. 2001, Domeier \& Nasby-Lucas 2007, 2008, 2012, Jorgensen et al. 2010, Anderson et al. 2011). Several abundance estimates suggest their numbers have declined during the 20th century, alongside the rise of industrialized fishing and marine recreation (Pepperell 1992, Reid \& Krogh 1992, Baum et al. 2003). Acknowledgement of the species' vulnerability to exploitation has prompted regional and international protection (i.e. threatened status in South Africa, USA, and Australia; World Conservation Union [IUCN] Red List status: Vulnerable A2cd+3cd Ver. 3.1; Convention on International Trade in Endangered Species [CITES]: Appendix II listing). Currently, a lack of information on abundance, genetic diversity, reproductive behavior and population structure prevents assessment of the efficacy of white shark conservation.

Many oceanic teleosts and elasmobranchs are presumed to lack population subdivision owing to their circumglobal distributions, lack of biogeographic barriers and high dispersal capacity. However, genetic analysis contradicts assumptions of panmixia in some species, e.g. narrow-barred Spanish mackerel Scomberomorus commerson (Sulaiman \& Ovenden 2010), Atlantic bluefin tuna Thunnus thynnus (Boustany et al. 2008, Riccioni et al. 2010) and whale shark Rhincodon typus (Castro et al. 2007). Some marine species range widely to feed; during this phase, individuals of the same species will be admixed, spatial genetic population subdivision will be minimal and gene flow will be assumed to be high. However, if individuals return to their birthplaces to breed and are sampled at that time, pronounced genetic population subdivision may be found. This behaviourranging widely but returning to favoured locations to breed - is termed reproductive philopatry (Hueter et al. 2005) and is exemplified by anadromous fishes such as salmonids (Narum et al. 2007). Several shark species, such as the common blacktip Carcharhinus limbatus and lemon shark Negaprion brevirostris (Feldheim et al. 2002, Keeney et al. 2005, Schultz et al. 2008) have genetically structured populations potentially driven by philopatric behaviour centred around nursery areas. Reproductive philopatry may also be gender biased. When sampled prior to dispersal after birth, or during aggregation for reproduction, a contrasting degree of population structure between uniparentally and biparentally inherited genetic markers implies that one gender is more philopatric, assuming genes are at mutation-genetic drift equilibrium (Prugnolle \& de Meeus 2002). For instance, male-biased dispersal has been suggested to explain the larger genetic population structure found in maternally inherited mitochondrial DNA (mtDNA) compared with biparentally inherited nuclear microsatellite DNA (nDNA) for the short-fin mako Isurus oxyrinchus (Schrey \& Heist 2003) and white sharks (Pardini et al. 2001). The genetic population structure of white sharks has not been investigated in Australia, and the scale at which population structure or philopatry of either gender occurs around Australia is unknown.

Both genetic and electronic tracking methods have been applied to determine broad-scale population structure and migratory habits of white sharks, but the results are equivocal. Rare transoceanic dispersal events have been tracked (Bonfil et al. 2005) and can be inferred from genetic studies (Pardini et al. 2001, Gubili et al. 2010). However, analysis of mtDNA shows high genetic differentiation between 3 regions, Australia/New Zealand, the western Indian Ocean and the northeastern Pacific Ocean (Pardini et al. 2001, Jorgensen et al. 2010), consistent with longterm genetic isolation possibly resulting from femalemediated philopatry. Despite genetic indications of gender-biased dispersal (Pardini et al. 2001), electronic tracking suggests that both genders exhibit site fidelity and cyclic oceanic excursions (Boustany et al. 2002, Bruce et al. 2006, Domeier \& Nasby-Lucas 2007, 2008, 2012, Jorgensen et al. 2010, Anderson et al. 2011). Although preliminary studies had suggested unconstrained mixture of sub-adult and adult white sharks throughout their Australasian range (Bruce et al. 2006), recent tracking of juveniles provides evidence for population segregation between eastern and southwestern Australia (Bruce \& Bradford 2012).

Genetic effective population size $\left(N_{\mathrm{e}}\right)$ is an important conservation measure for monitoring population size and genetic health (Reed \& Frankham 2003, Luikart et al. 2010, Hare et al. 2011). $N_{\mathrm{e}}$ represents the size of a theoretical 'Wright-Fisher population' that reflects the observed rate of genetic drift in a real population (Wright 1931, Hare et al. 2011). $N_{\mathrm{e}}$ also evaluates the future evolutionary resilience of a species; the lower $N_{\mathrm{e}}$ becomes, the greater the likelihood of deleterious allele fixation and loss of adaptive variation through genetic drift, thereby heightening the risk of population extinction (Frankham 2005, Hare et al. 2011). The timescale at which $N_{\mathrm{e}}$ is assessed can be historical or contemporary. The long-term or historical $N_{\mathrm{e}}$ (denoted $H N_{\mathrm{e}}$ ) is a function of popula- 
tion-wide genetic variation and the mutation rate, which estimates the harmonic mean effective population size per generation over approximately $4 N_{\mathrm{e}}$ generations (Hare et al. 2011). Converting $H N_{\mathrm{e}}$ into population estimates, Alter et al. (2007) inferred the historical population size of eastern Pacific grey whales Eschrichtius robustus to be 3 to 5 times higher than previous pre-whaling demographic population estimates, suggesting that the current population is still substantially depleted rather than recovered. The short-term or contemporary $N_{\mathrm{e}}$ (denoted $C N_{\mathrm{e}}$ ) can be derived from the magnitude of recent genetic drift within a population and approximates the mean number of breeding individuals contributing offspring per generation (Hoarau et al. 2005, Portnoy et al. 2009). $C N_{\mathrm{e}}$ estimates for western Atlantic sandbar shark Carcharhinus plumbeus populations were found to be approximately half the adult population census estimates $\left(N_{C}\right)$. This may serve as an example of the relationship of $C N_{\mathrm{e}}$ to $N_{\mathrm{C}}$ in other elasmobranchs with similar life histories and indicates that for this species a significant proportion of each population contributes to recruitment. In contrast, highly fecund teleost fish populations have $C N_{\mathrm{e}} / N_{\mathrm{C}}$ ratios of $10^{-3}$ to $10^{-6}$ (Hoarau et al. 2005, Portnoy et al. 2009), which may indicate that relatively few parents contribute recruits to the next generation. It also suggests that this commercially harvested shark population may be sensitive to depletion like exploited marine mammal populations that have similar $C N_{\mathrm{e}} / N_{\mathrm{C}}$ ratios, e.g. Bering Sea bowhead whales Balaena mysticetus (Shelden et al. 2001) and Californian sea otters Enhydra lutris (Ralls et al. 1983). Historic and contemporary Australian white shark population sizes are unknown, but could be approximated from measures of genetic diversity and genetic drift, additionally providing an assessment of their genetic health and the effectiveness of conservation policies.

We investigated the genetic population structure and the existence of fine-scale philopatry for Australian white sharks within and between Australian coastal regions using mtDNA control region (CR) sequences and 6 nDNA microsatellite loci. Next, we generated $N_{\mathrm{e}}$ estimates from the microsatellite loci: $H N_{\mathrm{e}}$ as a coarse measure of historic white shark population size and $C N_{\mathrm{e}}$ to indicate the current breeding population size and genetic health of Australian white sharks. We predicted that white shark $C N_{\mathrm{e}}$ would be significantly lower than $H N_{\mathrm{e}}$, although not approaching critical genetic thresholds given a history of protection from exploitation. The present study provides data on white shark population structure and effective population sizes and fresh insight into reproductive behaviour - measures critical for evaluating their genetic health and assessing the effectiveness of their protection in Australian waters.

\section{MATERIALS AND METHODS}

\section{Sample acquisition and demographics}

Tissue samples $(\mathrm{n}=97)$ and associated data (e.g. gender, total length, capture location) spanning $21 \mathrm{yr}$ (Table 1) were acquired from incidental captures $(n=62)-$ e.g. New South Wales (NSW) bather protection program (Green et al. 2009) and commercial and recreational fisheries by-catch - and from sharks

Table 1. Carcharodon carcharias. Source and number (n) of tissue samples and mitochondrial DNA control region sequences (mtDNA CR). The region represents the general area from which sharks were sampled

\begin{tabular}{|c|c|c|c|c|}
\hline Region & Sample type & $\mathrm{n}$ & Source & GenBank Accession No. \\
\hline Australia & Tissue & $\begin{array}{l}68 \\
17 \\
13 \\
16\end{array}$ & $\begin{array}{l}\text { CSIRO, Australian } \\
\text { Federal Government } \\
\text { Griffith University, Gold Coast, Queenslanc } \\
\text { The University of Queensland, Brisbane } \\
\text { NSW Department of Primary Industries }\end{array}$ & HQ414073-HQ414086 \\
\hline Australia & mtDNA CR sequences & 12 & & \\
\hline New Zealand & mtDNA CR sequences & 4 & GenBank popset (Pardini et al. 2001) & AY026196-AY026224 \\
\hline $\begin{array}{l}\text { Western Indian } \\
\text { Ocean }\end{array}$ & mtDNA CR sequences & 13 & & \\
\hline $\begin{array}{l}\text { northeastern } \\
\text { Pacific }\end{array}$ & mtDNA CR sequences & 20 & GenBank popset (Jorgensen et al. 2010) & GU002302-GU002321 \\
\hline $\begin{array}{l}\text { Northwest } \\
\text { Atlantic }\end{array}$ & mtDNA CR sequences & 2 & GenBank popset (Gubili et al. 2010) & HQ540294-HQ540298 \\
\hline Mediterranean & mtDNA CR sequences & 3 & & \\
\hline
\end{tabular}


tagged specifically for tracking research $(n=35)$ by the Commonwealth Scientific and Industrial Research Organization (CSIRO). All tagged sharks were released alive after measurement and attachment of electronic tracking devices, but the mortality rates of these sharks and the sharks sampled from other sources are not known. Sampling of sharks was predominantly opportunistic from 1989 to 2004, with approximately 2 sharks sampled per year, the majority from the provinces of South Australia $\left(\mathrm{SA}_{i} \mathrm{n}=17\right.$ ), then NSW ( $\mathrm{n}=5$ ), followed by Queensland (QLD; $\mathrm{n}=5$ ), Tasmania (TAS; $\mathrm{n}=5$ ) and Western Australia (WA; $\mathrm{n}=1$ ). From 2005 to 2009, CSIRO's tagging program boosted the numbers of samples by 35: 21 came from NSW, 13 from SA and 1 from WA. A further 29 samples were obtained through bather protection and by-catch: 9 from QLD, 17 from NSW and 3 from an unrecorded location. Over that period (2005 to 2009) an average of 13 sharks $\mathrm{yr}^{-1}$ were sampled from all sources. All the samples were divided by capture province and grouped into an eastern or southwestern region of Australia (Fig. 1). Samples of unknown capture location $(\mathrm{n}=3)$ were included in analyses unless capture region was integral.

We defined mature sharks by the total length (TL; all lengths are TL unless otherwise specified) at which each gender is considered by Bruce (2008) as sexually mature $(>360 \mathrm{~cm}$ [males]; $>450 \mathrm{~cm}$ [females]). Sharks below these sizes were considered juveniles. Sampled shark TL ranged from 138 to
$510 \mathrm{~cm}(\bar{x}=287 \mathrm{~cm})$ as compared with the known TL range of the species of 130 to 600 or $700 \mathrm{~cm}$ (Bruce 2008). Juvenile sharks made up $71 \%(n=69)$ of the total. The sex ratio of white sharks in the wild appears to be close to parity (Domeier \& NasbyLucas 2007); additionally, they are thought to have a neonate embryonic sex ratio of $1: 1$, similar to our samples' female to male sex ratio (1.2:1) (46 females, 40 males and 11 of unknown gender).

\section{Laboratory procedures}

Tissue samples consisting of muscle or fin cartilage (15 to $20 \mathrm{mg}$ ) were diced and soaked overnight in $1 \times$ TE buffer (10 mM pH 8.0; Tris-HCl, 1 mM EDTA). Genomic DNA extraction was performed with Qiagen P/L DNEasy extraction kits. Extracted DNA was standardized to $10 \mathrm{ng}^{-1} \mathrm{l}^{-1}$ prior to amplification. After DNA extraction, tissue samples were archived in $20 \% \mathrm{DMSO}$, saturated with $\mathrm{NaCl}$ and frozen at $-80^{\circ} \mathrm{C}$.

For mtDNA amplification, we designed a forward primer (GWSMT1F, 5'-TTA CAA CCC AGG GGG TAT CCT-3') to bind downstream of a heteroplasmic thymine sequence at 173 base pairs (bp) encountered by Pardini et al. (2001). The reverse primer (GWSMT1R, 5'-AGC CAA ACA TCC ATT TGG CCT-3') complemented the forward primer annealing temperature $\left(61^{\circ} \mathrm{C}\right)$. Polymerase chain reaction (PCR) was performed in a $10.0 \mu$ reaction composed

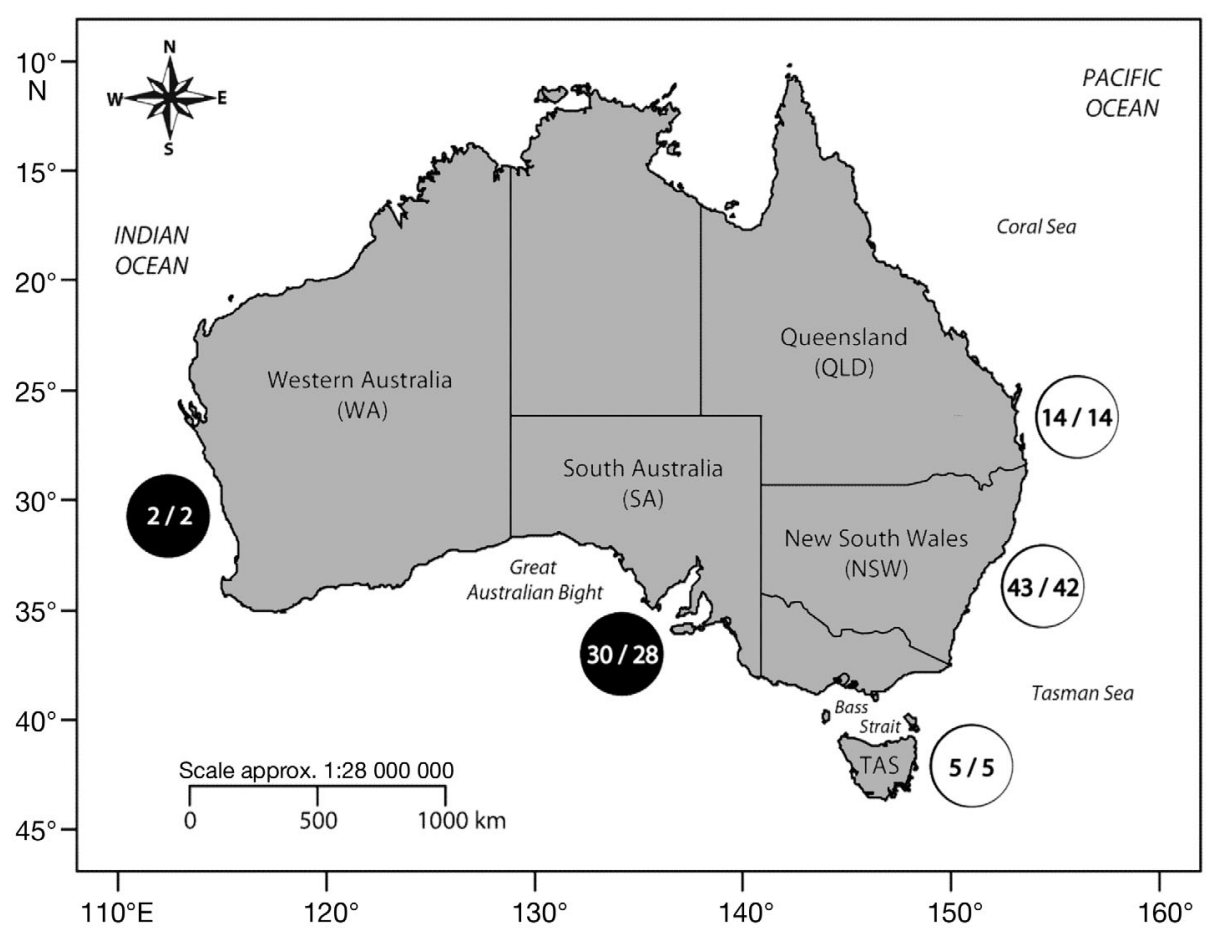

Fig. 1. Carcharodon carcharias. Number of individuals genotyped with nuclear DNA microsatellite loci (first number in circles) and sequenced for mitochondrial DNA control region (second number in circles) from provinces of Australia and their grouping by region. Black circles represent samples comprising the southwestern region. White circles represent the eastern region. Circle positions are relative to political provinces, as delineated by the political boundaries shown on the land masses, and represent the general location where sharks were sampled 
of $1.0 \mu \mathrm{l}$ DNA template, $0.2 \mu \mathrm{M}$ of both primers, $1 \times$ PCR buffer (10× ImmoBuffer, BIOLINE P/L), $4.0 \mathrm{mM}$ $\mathrm{MgCl}_{2}, 0.5 \mathrm{mM}$ dNTP mix (25.0 mM of each dNTP) and $0.5 \mathrm{U}$ DNA polymerase (Immolase Hot Start Taq, BIOLINE). PCR cycling (Mastercycler Pro, Eppendorf $\mathrm{AG}$ ) conditions were as follows: $10 \mathrm{~min}$ polymerase activation at $95^{\circ} \mathrm{C}$, then 30 cycles of $15 \mathrm{~s}$ denaturation at $94^{\circ} \mathrm{C}, 30 \mathrm{~s}$ annealing at $61^{\circ} \mathrm{C}$ and 1 min elongation at $72^{\circ} \mathrm{C}$, followed by 7 min extension at $72^{\circ} \mathrm{C}$. PCR products were purified by combining $3.0 \mu \mathrm{l}$ DNA template, $0.5 \mu$ l Exonuclease I $(1 \times$, New England BioLabs), 5.0 U Antarctic phosphatase (1 $\times$, New England BioLabs) and 4.5 $\mu$ l MilliQ $\mathrm{H}_{2} \mathrm{O}$, which was heated to $37^{\circ} \mathrm{C}$ for $30 \mathrm{~min}$, then $80^{\circ} \mathrm{C}$ for $15 \mathrm{~min}$. Dye-termination sequencing was performed (Big Dye Terminator v3.1 Cycle Sequencing Kit, Applied Biosystems) with an Applied Biosystems 3130 XL capillary electrophoresis genetic analyser.

Microsatellite loci Ccar1, Ccar9, Ccar13, Ccar19, Ccar6.27x and Iox10 (Table 2) were amplified in an 8.0 $\mu \mathrm{l} \mathrm{PCR}$ reaction of $0.17 \mu \mathrm{M}$ fluorescent FAMlabelled M13 primer, $0.17 \mu \mathrm{M}$ reverse primer, $0.08 \mu \mathrm{M}$ forward primer (with a 23 nucleotide M13 extension), $1 \times$ PCR buffer, $4.0 \mathrm{mM}$ of $\mathrm{MgCl}_{2}, 0.5 \mathrm{mM}$ dNTP mix and $0.5 \mathrm{U}$ of DNA polymerase. PCR amplification conditions required $95^{\circ} \mathrm{C}$ for $10 \mathrm{~min}$, then 35 cycles of $94^{\circ} \mathrm{C}$ for $15 \mathrm{~s}, 30 \mathrm{~s}$ at the locus-specific annealing temperature $\left(64^{\circ} \mathrm{C}\right.$ for Ccar1, Ccar9, CCar19 and Iox $10,63^{\circ} \mathrm{C}$ for $C$ car 13 and $61.5^{\circ} \mathrm{C}$ for Ccar6.27x), then $1 \mathrm{~min}$ at $72^{\circ} \mathrm{C}$, and extended at $72^{\circ} \mathrm{C}$ for $7 \mathrm{~min}$. PCR product was diluted 1:40 with MilliQ $\mathrm{H}_{2} \mathrm{O}$ and automated fragment separation performed (ABI 3130 XL, Applied Biosystems).

\section{Data analysis}

Forward and reverse mtDNA sequence traces were imported into CodonCode Aligner Version 3.5 (CodonCode), trimmed and edited by eye. Sequences were aligned with the ClustalW algorithm implemented in MEGA Version 4 (Tamura et al. 2007). The aligned sequences, including indels, were exported to GenAlEx Version 6.3 (Peakall \& Smouse 2006) and Arlequin Version 3.5.1.2 (Excoffier \& Lischer 2010) to identify and characterize haplotypes. Sequence diversity indices, polymorphism statistics, nucleotide proportions and diversity $(\pi)$, and haplotype number and diversity $(h)$ were obtained with Arlequin using the Tamura-Nei model (Tamura \& Nei 1993) with gamma set to 0.5 (Gubili et al. 2010).

Comparison with mtDNA CR sequences of previous studies (Table 1), trimmed to $842 \mathrm{bp}$, was performed to reveal any new haplotypes. Pardini et al. (2001) included some of the Australian tissue samples used here, so to avoid duplication or unequal weighting of Australian haplotypes, Pardini's Australian mtDNA sequences were not included if they matched haplotypes found by our study $(\mathrm{N}=6)$. Phylogenetic relationships were assessed with a neighbour-joining (Saitou \& Nei 1987) bootstrap consensus phylogram generated with MEGA 4. The relative frequency of Australian/New Zealand haplotypes and the mutational steps between global haplotypes was assessed by generating a statistical parsimony haplotype network with TCS Version 1.21 (Clement et al. 2000). The $95 \%$ parsimony haplotype connection limit was progressively relaxed until a fully connected global network was attained (sequence gaps were assumed to represent a fifth state).

Genemapper Version 3.7 (Applied Biosystems) was used to bin microsatellite alleles. Genotyping errors and null allele probabilities were tested for using Microchecker Version 2.2.3 (Van Oosterhout et al. 2004). Microsatellite genotypes were compared with SHAZA V1.0 (Macbeth et al. 2011) to assess whether duplicate genotypes represent the same (e.g. unintentionally re-sampled) or different (e.g. shadow) animals. Alleles were analysed for conformance to Hardy-Weinberg equilibrium and for linkage dise-

Table 2. Carcharodon carcharias. Summary of Australian-sourced nuclear DNA microsatellite loci data showing the number of sharks genotyped $(\mathrm{n})$, the number of alleles $\left(\mathrm{N}_{\mathrm{a}}\right)$, the average observed $\left(H_{\mathrm{O}}\right)$ and expected $\left(H_{\mathrm{E}}\right)$ heterozygosity, genotyping success rate $(\%)$, and GenBank accession number

\begin{tabular}{|c|c|c|c|c|c|c|}
\hline Locus & $\mathrm{n}$ & $\mathrm{N}_{\mathrm{a}}$ & $H_{\mathrm{O}}$ & $H_{\mathrm{E}}$ & Success (\%) & GenBank Accession No. \\
\hline Ccar1 & 93 & 6 & 0.634 & 0.725 & 96 & AF216865 (Pardini et al. 2000) \\
\hline Ccar13 & 87 & 10 & 0.805 & 0.785 & 90 & AF184087 (Pardini et al. 2000) \\
\hline Ccar19 & 94 & 3 & 0.426 & 0.519 & 97 & AF184087 (Pardini et al. 2000) \\
\hline Ccar6.27x & 91 & 4 & 0.571 & 0.516 & 94 & Unpublished (Gubili et al. 2009) \\
\hline Ccar9 & 94 & 15 & 0.894 & 0.859 & 97 & AF216866 (Pardini et al. 2000) \\
\hline Iox10 & 97 & 5 & 0.742 & 0.702 & 100 & AF426735 (Schrey \& Heist 2002) \\
\hline
\end{tabular}


quilibrium by Genepop web Version 4.0 (Rousset 2008). The microsatellite allelic diversity indices of expected and observed heterozygosity and allele numbers per locus were obtained with Arlequin.

Population structure was evaluated within and between the eastern and southwestern samples using Wright's F-statistic, $F_{\mathrm{ST}}$ (Wright 1950, 1965), with haplotype frequencies (mtDNA) or allele frequencies (microsatellite loci) by Arlequin (100000 permutations). The significance of multiple comparisons was evaluated after Bonferroni correction at a global significance level of 0.05 (Rice 1989). To assess the possible effects of age-specific dispersal rates on population structure, each analysis was performed with and without adult sharks. Analyses were repeated with and without sharks from the east coast population that were subsequently revealed to have strong affinities with western Indian Ocean populations.

To estimate $H N_{\mathrm{e}}$, we used the Bayesian coalescent genealogy sampler MIGRATE-n Version 3.1.6 (Beerli 2008) with microsatellite genotypes to generate a measure of genetic diversity, theta $(\theta)$. Initial runs of MIGRATE-n used default parameters to establish the potential range of $\theta$. Convergence on the posterior distribution of $\theta$ was then established with thorough search parameters (10000 recorded steps with 100 record increments, 10 heated chains with 1 as the swapping interval and with 100000 trees discarded as burn-in). MIGRATE-n runs requiring intensive processing were performed by the Computational Biology Service Unit (CBSU) at Cornell University, USA. In the absence of a species-specific mutation rate, vertebrate microsatellite mutation rates $(\mu)$ of $10^{-3}, 10^{-4}$ and $10^{-5}$ mutations gamete ${ }^{-1}$ generation $^{-1}$ (Bagley et al. 1999) were substituted into the equation $\theta=4 N_{\mathrm{e}} \mu$ to produce lower, middle and upper estimates of $H N_{\mathrm{e}}$, respectively.

$C N_{\mathrm{e}}$ was estimated from the amount of pairwise linkage disequilibrium between microsatellite loci (Hill 1981, Waples 2006). The program LDNe Version 1.31 (Waples \& Do 2008) was used to produce $C N_{\mathrm{e}}$ estimates for Australia as a whole and for each region, since $C N_{\mathrm{e}}$ estimates may be biased where population structure exists (Palstra \& Ruzzante 2008). Random mating was chosen over monogamy for the reproductive model, as white shark mating behaviour is not understood. Rare alleles upwardly bias $C N_{\mathrm{e}}$ estimates under simulated conditions ( $\mathrm{n}=100$, 20 loci with 10 alleles locus ${ }^{-1}$ ) (Waples \& Do 2010). Following Waples \& Do (2010), who recommend a $P_{\text {crit }}$ (allele frequency exclusion criterion) of 0.02 when sample sizes are $>25$, for each sample group we raised the $P_{\text {crit }}$ value of the LDNe software from 0.02 , in increments of 0.01 , to pass through the range recommended by Waples \& Do $(2008,2010)$ at which there is least trade-off between bias and precision $\left(0.02 \leq P_{\text {crit }} \leq 0.05\right)$. We continued to increment $P_{\text {crit }}$ through and beyond this range until the first occurrence of a finite point-estimate of $C N_{\mathrm{e}}$, which was then accepted as the best estimate.

\section{RESULTS}

\section{Summary statistics for mtDNA and haplotype analysis}

MtDNA CR sequences (842 bp) were obtained for 94 individual white sharks Carcharodon carcharias. Fourteen unique haplotypes were found, 9 of which were previously undescribed. The overall haplotype diversity $(h, \pm \mathrm{SE})$ was $0.8776 \pm 0.0148$, and the nucleotide diversity $(\pi, \pm \mathrm{SE})$ was $0.00855 \pm 0.00448$. There were 51 polymorphic sites, composed of 4 indels, 40 transitions and 8 transversions (Tables 3 \& 4).

Phylogenetic analysis revealed that 2 eastern Australian haplotypes (Haplotypes 13 \& 14; Table 4, Fig. 2; GenBank Accession Nos. HQ414073 \& HQ414074) were substantially more similar to western Indian Ocean (WIO) white shark haplotypes (Haplotypes 20 \& 22 to 25; Fig. 2; GenBank Accession Nos. AY026212 to AY20224); these sharks are referred to here as WIO-like (WIOL). Only a single nucleotide transition distinguished WIOL from WIO haplotypes. The mean net distance between WIO and the Australia/New Zealand clade was $0.055 \pm$ 0.009 (base substitutions per site, $\pm \mathrm{SE}$ ), equivalent to 42 mutational steps (Fig. 2). Six sharks from both eastern and southwestern Australia had haplotypes identical to those originally sampled in New Zealand (Haplotypes 11 \& 8; Fig. 2; GenBank Accession Nos. AY026209/HQ414076 and AY026210/HQ414079).

\section{Summary statistics for microsatellite loci}

Likelihood-based genotype matching by SHAZA identified 6 pairs and 1 triplet of exact duplicate genotypes. CSIRO confirmed that 1 duplicate pair represented a previously unrecognized recapture event and that 3 other duplicate pairs were duplicated tissue samples. The remaining duplicates could not be easily explained. Pre-PCR processing had been conducted under sterile conditions and with multiple negative controls during PCR processing, so contamination was considered unlikely. For each set of duplicate samples, the sample with least demo- 
Table 3. Carcharodon carcharias. Australian-sourced partial mitochondrial DNA control region haplotypes (1 to 12) showing nucleotide position of polymorphic sites, haplotype frequencies $(h)$, sample sizes (N), number of haplotypes and sequence diversity indices. Western Indian Ocean-like haplotypes 13 and 14 are excluded (see Table 4). NA: not applicable; dots: same nucleotide as haplotype 1; dashes: haplotype not found in province

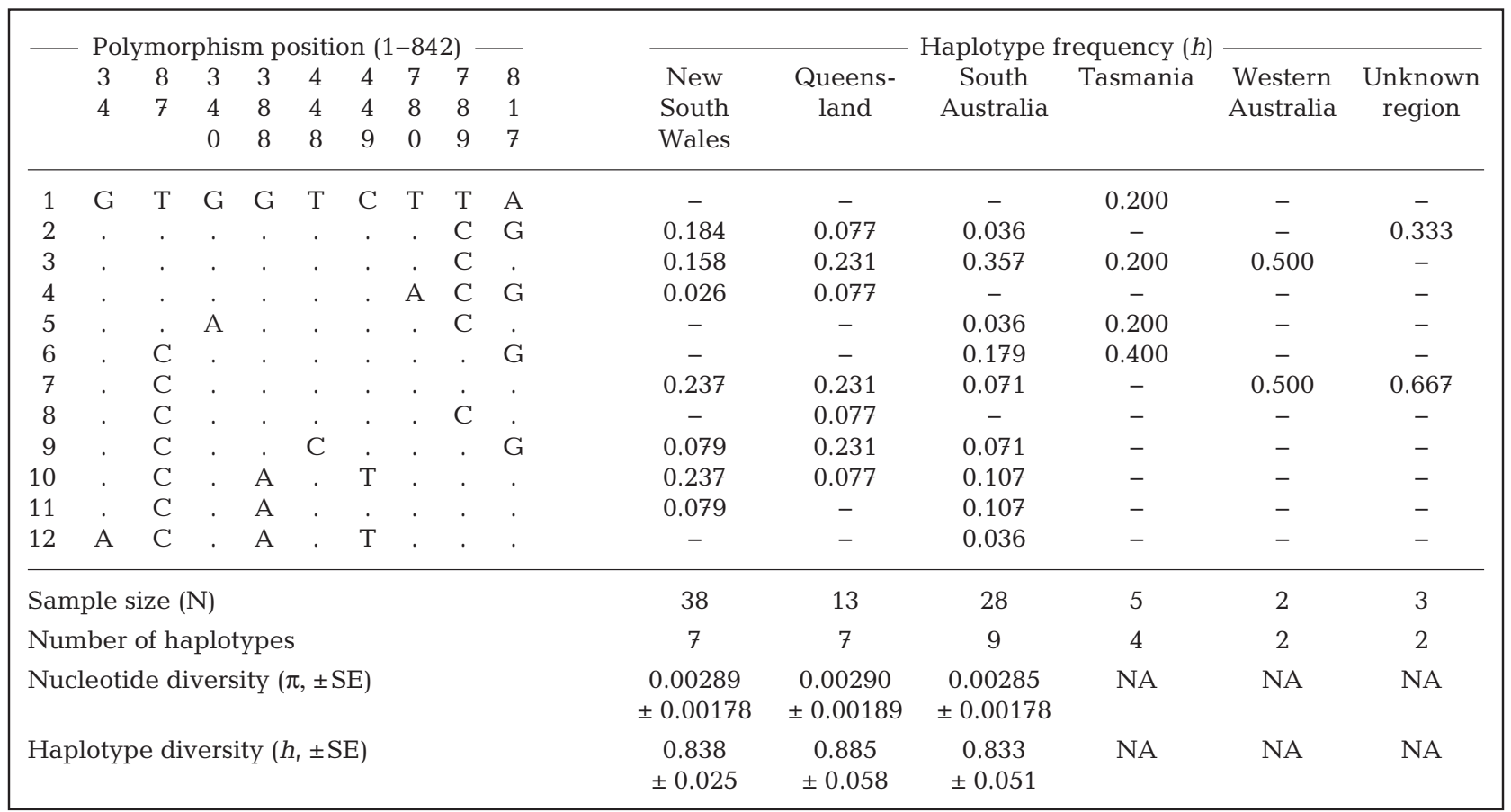

Table 4. Carcharodon carcharias. Australian-sourced western Indian Oceanlike (WIOL) partial mitochondrial DNA control region haplotypes (13 \& 14) showing nucleotide position of polymorphic sites, haplotype frequencies $(h)$, sample sizes (N), number of haplotypes, collection province and sequence diversity indices, including totals for WIOL plus non-WIOL haplotypes. NA: not applicable; dashes: haplotype not found in province

\begin{tabular}{|c|c|c|c|}
\hline \multicolumn{2}{|c|}{ Polymorphism position (1-842) } & \multicolumn{2}{|c|}{ Haplotype frequency $(h)$} \\
\hline $\begin{array}{ll}t & 1 \\
& \end{array}$ & 7 & New & Queens- \\
\hline 4 & 6 & South & land \\
\hline 0 & 4 & Wales & \\
\hline 13 & $\mathrm{~T}$ & 0.250 & - \\
\hline 14 & $\mathrm{C}$ & 0.750 & 1 \\
\hline \multicolumn{2}{|c|}{ Sample size $(\mathrm{N})$} & 4 & 1 \\
\hline \multicolumn{2}{|c|}{ Number of haplotypes } & 2 & 1 \\
\hline \multicolumn{2}{|c|}{ Nucleotide diversity $(\pi, \pm \mathrm{SE})$} & NA & NA \\
\hline \multicolumn{2}{|c|}{ Haplotype diversity $(h, \pm \mathrm{SE})$} & NA & NA \\
\hline \multicolumn{4}{|c|}{ WIOL plus non-WIOL haplotypes (separated by 44 polymorphic sites) } \\
\hline \multicolumn{2}{|c|}{ Sample size $(\mathrm{N})$} & 42 & 14 \\
\hline \multicolumn{2}{|c|}{ Number of haplotypes } & 9 & 8 \\
\hline \multicolumn{2}{|c|}{ Nucleotide diversity $(\pi, \pm \mathrm{SE})$} & $\begin{array}{c}0.01294 \\
\pm 0.00667\end{array}$ & $\begin{array}{c}0.01093 \\
\pm 0.00601\end{array}$ \\
\hline \multicolumn{2}{|c|}{ Haplotype diversity $(h, \pm \mathrm{SE})$} & $\begin{array}{c}0.8641 \\
\pm 0.0226\end{array}$ & $\begin{array}{c}0.9011 \\
\pm 0.0523\end{array}$ \\
\hline
\end{tabular}

graphic information was excluded from analyses.

Genotyping 97 white sharks (Fig. 1) using 6 microsatellite loci produced between 3 to 15 alleles locus ${ }^{-1}$. Observed heterozygosity $\left(H_{\mathrm{O}}\right)$ per locus ranged from 0.426 to 0.894 and expected heterozygosity $\left(H_{\mathrm{E}}\right)$ per locus ranged between 0.516 and 0.859 (Table 2). Microchecker highlighted a potential null allele for locus Ccar1 at the $95 \%$ confidence interval (CI). However, this locus conformed to Hardy-Weinberg equilibrium expectations $(\mathrm{p}=0.62)$, so it was retained for subsequent analyses. All other loci were within Hardy-Weinberg equilibrium expectations, and no linkage disequilibrium was detected after Bonferroni correction.

\section{Population structure}

Population structure was detected with both mtDNA and microsatellite markers. The mtDNA $F_{\mathrm{ST}}$ between eastern 

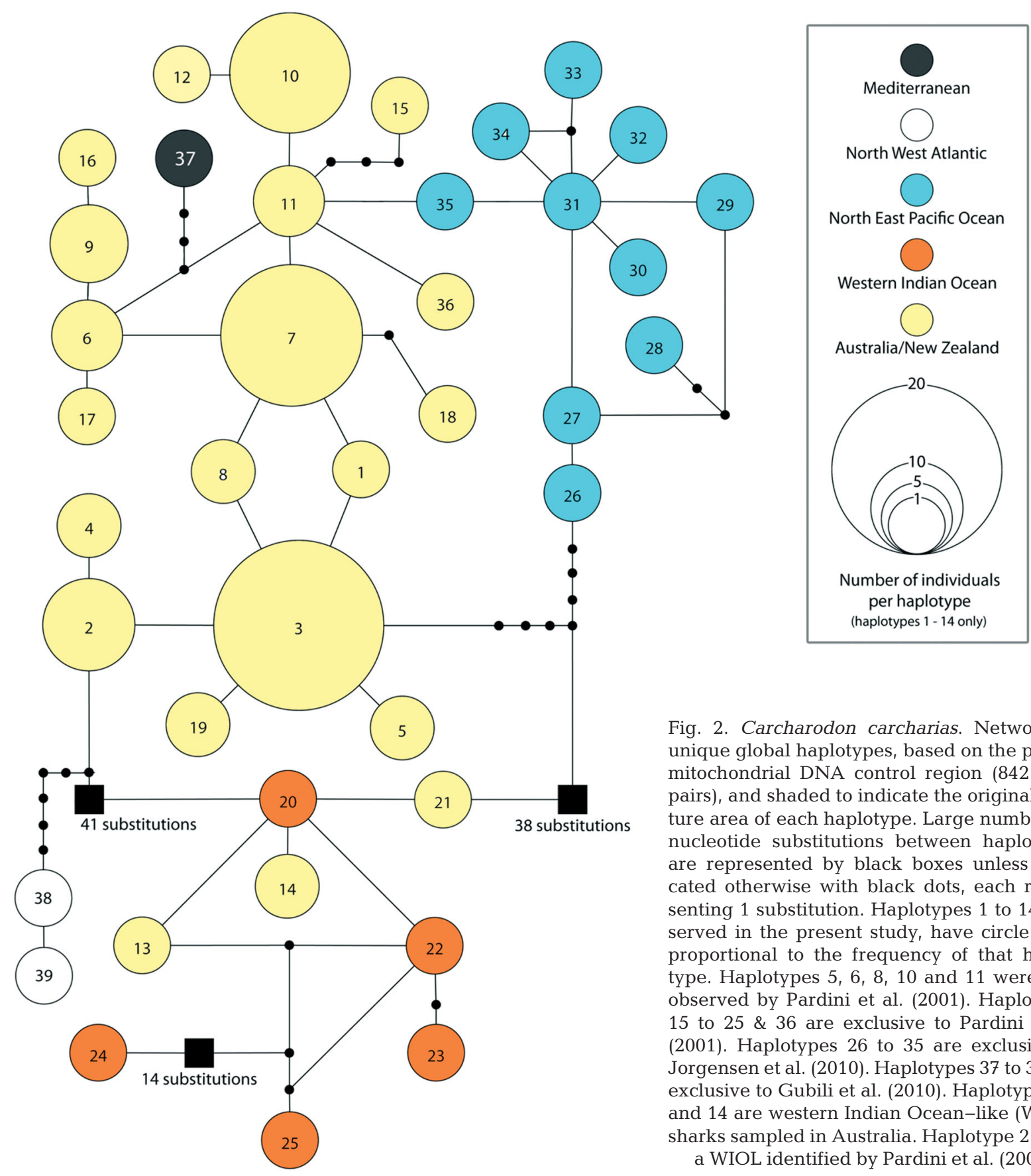

Fig. 2. Carcharodon carcharias. Network of unique global haplotypes, based on the partial mitochondrial DNA control region (842 base pairs), and shaded to indicate the original capture area of each haplotype. Large numbers of nucleotide substitutions between haplotypes are represented by black boxes unless indicated otherwise with black dots, each representing 1 substitution. Haplotypes 1 to 14, observed in the present study, have circle sizes proportional to the frequency of that haplotype. Haplotypes 5, 6, 8, 10 and 11 were also observed by Pardini et al. (2001). Haplotypes 15 to 25 \& 36 are exclusive to Pardini et al. (2001). Haplotypes 26 to 35 are exclusive to Jorgensen et al. (2010). Haplotypes 37 to 39 are exclusive to Gubili et al. (2010). Haplotypes 13 and 14 are western Indian Ocean-like (WIOL) sharks sampled in Australia. Haplotype 21 was a WIOL identified by Pardini et al. (2001)

and southwestern sharks was $0.14174(\mathrm{p}<0.0001)$ (Table 5a) and was $0.17348(\mathrm{p}<0.0001)$ for juvenile shark samples alone (Table $5 \mathrm{~b}$ ). The microsatellite $F_{\mathrm{ST}}$ between the eastern and southwestern samples was 0.00927, which was significant at 0.05 but not significant after Bonferroni adjustment. For juvenile shark samples the microsatellite $F_{\mathrm{ST}}$ was non-significant. The microsatellite locus Iox10 produced the largest locus-by-locus $F_{\mathrm{ST}}$ between the eastern and southwestern samples $\left(F_{\mathrm{ST}}=0.03778, \mathrm{p}=0.00553\right)$.
Only mtDNA showed evidence of population structure between locations along the east coast. Between NSW and QLD the mtDNA $F_{\text {ST }}$ was 0.11933 (p < 0.0001) (Table 6). Evaluating juvenile samples alone, the magnitude and significance of the mtDNA $F_{\mathrm{ST}}$ was similar at both regional and provincial scales. The microsatellite $F_{\mathrm{ST}}$ did not show significance between NSW and QLD, but was significant at 0.05 between NSW and SA $\left(F_{\mathrm{ST}}=0.01183\right)$, although not significant after Bonferroni correction. 
Table 5. Carcharodon carcharias. Genetic population structure and significance level $\left(F_{\mathrm{ST}} / \mathrm{p}\right)$ for pairwise comparisons between Australian regions. $F_{\mathrm{ST}}$ values below diagonal are based on mitochondrial DNA (mtDNA), and above diagonal, microsatellite loci (nDNA). $\mathrm{N}$ and $\mathrm{n}$ represent mtDNA and nDNA sample sizes, respectively. ${ }^{*}$ : significant at $\mathrm{p} \leq 0.05$; ^: comparison not significant after Bonferroni correction, $\alpha=0.0125$

\begin{tabular}{|lccc|}
\hline n/N & Region & $\begin{array}{c}\text { Eastern Australia } \\
\text { (EA) }\end{array}$ & $\begin{array}{c}\text { Southwestern } \\
\text { Australia (SWA) }\end{array}$ \\
\hline \multicolumn{3}{l}{ (a) All } & animals \\
$62 / 61$ & EA & & $0.00927 / 0.03186^{*, \wedge}$ \\
$32 / 30$ & SWA & $0.14174 / 0.00000^{*}$ & \\
(b) Juvenile animals only & $0.00140 / 0.35181$ \\
$55 / 54$ & EA & SWA & $0.17348 / 0.00003^{*}$ \\
$13 / 12$ & SW \\
\hline
\end{tabular}

The mtDNA and microsatellite $F_{\mathrm{ST}}$ values increased slightly in magnitude when samples with WIOL haplotypes were excluded, but the pattern of $F_{\mathrm{ST}}$ significance was unchanged. For example, without the WIOL samples, the mtDNA $F_{\mathrm{ST}}$ between the eastern and southwestern coasts was 0.15124 (p < 0.0001 ) and the microsatellite $F_{\mathrm{ST}}$ between the eastern and southwestern samples was 0.00931 ( $\mathrm{p}=$ 0.03537), and was again non-significant after correction for multiple comparisons.

\section{Estimates of genetic effective population size}

As expected, the contemporary estimates of genetic effective population size $\left(C N_{\mathrm{e}}\right)$ were less than the historical estimates $\left(H N_{\mathrm{e}}\right)$. Coalescent-based estimates of $H N_{\mathrm{e}}$ derived from Bayesian search of microsatellite marker genealogies gave $\theta$ values for individual loci ranging from 1.2 to 13.0, with a mean of 4.9 and median of 5.2. Applying general microsatellite loci mutation rates and inputting the $\theta$ posterior distribution mode of 5.36 produced $H N_{\mathrm{e}}$ estimates ranging from approximately 3000, using a faster mutation rate $\left(10^{-3}\right)$, to 268000 for a slower mutation rate $\left(10^{-5}\right)$ (Table 7 ).

Estimates of $C N_{\mathrm{e}}$ resulted in a point estimate of 1512 (95\% CI $=122-\infty, \mathrm{n}=97$ ) for the Australian population. This estimate was achieved when $P_{\text {crit }}$ was 0.06 , i.e. above the $P_{\text {crit }}$ range $(0.02$ to 0.05$)$ at which simulated $C N_{\mathrm{e}}$ estimates are balanced in precision and bias relative to the true $C N_{\mathrm{e}}$ (Waples \& Do 2008, 2010). Finite point-estimates for the eastern coast population could not be achieved at an acceptably low $P_{\text {crit }}$ value $\left(C N_{\mathrm{e}}=380, P_{\text {crit }}=0.18,95 \% \mathrm{CI}=31-\infty\right.$, $\mathrm{n}=62$ ). The $P_{\text {crit }}$ of the southwestern estimate was more acceptable $\left(C N_{\mathrm{e}}=693, P_{\text {crit }}=0.07,95 \% \mathrm{CI}=28-\right.$ $\infty, \mathrm{n}=32$ ), but above the simulated optimal $P_{\text {crit }}$ range.
Table 6. Carcharodon carcharias. Genetic population structure and significance level $\left(F_{S T} / p\right)$ for pairwise comparisons between Australian provinces. $F_{\mathrm{ST}}$ values below diagonal are based on mitochondrial DNA (mtDNA), and above diagonal, microsatellite loci (nDNA). $\mathrm{N}$ and $\mathrm{n}$ represent mtDNA and nDNA sample sizes, respectively, and include both adult and juvenile animals. ${ }^{*}$ : significant at $\mathrm{p} \leq 0.05 ;{ }^{\wedge}$ : comparison not significant after Bonferroni correction, $\alpha=0.00833$

\begin{tabular}{|ccccc|}
\hline n/N & Province & $\begin{array}{c}\text { New South } \\
\text { Wales (NSW) }\end{array}$ & $\begin{array}{c}\text { Queensland } \\
\text { (QLD) }\end{array}$ & $\begin{array}{c}\text { South Australia } \\
\text { (SA) }\end{array}$ \\
\hline $43 / 42$ & NSW & & $0.00601 / 0.21124$ & $\begin{array}{c}0.01183 / 0.02499^{*, \wedge} \\
0.00249 / 0.32105\end{array}$ \\
$14 / 14$ & QLD & $0.11933 / 0.00013^{*}$ & & \\
$30 / 28$ & SA & $0.15064 / 0.00000^{*}$ & $0.13546 / 0.00011^{*}$ & \\
\hline
\end{tabular}

Table 7. Carcharodon carcharias. Historic genetic effective population size estimates $\left(H N_{\mathrm{e}}\right)$ where genetic diversity $(\theta)$ is derived from Australian-sourced nuclear DNA microsatellite alleles. Microsatellite loci mutation rates ( $\mu$ : mutations per gamete per generation), are arranged from faster to slower: $\mu_{1}=10^{-3}$, $\mu_{2}=10^{-4}$ and $\mu_{3}=10^{-5}$. Ranges in brackets represent lower and upper $95 \%$ confidence intervals

\begin{tabular}{|cccc|}
\hline$\theta$ & $H N_{\mathrm{e}}\left(\mu_{1}\right)$ & $H N_{\mathrm{e}}\left(\mu_{2}\right)$ & $H N_{\mathrm{e}}\left(\mu_{3}\right)$ \\
\hline 5.36 & 2681 & 26813 & 268125 \\
$(4.35-6.60)$ & $(2218-3300)$ & $(21750-33000)$ & $(217500-330000)$ \\
\hline
\end{tabular}

\section{DISCUSSION}

\section{Population structure around the Australian continent}

We found maternal genetic population subdivision between eastern and southwestern coastal regions of Australia. Previous investigations of white shark populations had revealed only large-scale mtDNA population structure consistent with long-term isolation of the Australian/New Zealand population from those of the western Indian Ocean $\left(F_{\mathrm{ST}}=0.81\right.$ to 0.93) and the northeastern Pacific Ocean $\left(F_{\mathrm{ST}}=0.68\right)$ (Pardini et al. 2001, Jorgensen et al. 2010). Immigration rates as low as 1 individual per generation may obscure population structure resulting from genetic drift (Wright 1931, Spieth 1974), but, in reality, up to 10 migrants per generation may be required (Mills \& Allendorf 1996). The magnitude of mater- 
nal population differentiation within Australian waters was less than that between Australia and other continents, indicating that maternal gene flow and hence migration is greater at an Australian regional scale, although still constrained. Following Pardini et al. (2001), we propose that reproductive philopatry is a behavioural barrier restricting maternal gene flow around Australia, despite the high vagility of white sharks (Bruce et al. 2006) and a lack of current or ancient physical barriers. The maternally inherited mtDNA white shark population structure evident in predominately immature Australian populations suggests that, for many generations, females have returned to the same coastal regions for parturition and that the juvenile sharks sampled have remained in the natal area. Such reproductive philopatry is observed in several shark species (Hueter et al. 2005), including other vagile but coastally orientated species such as sandbar Carcharhinus plumbeus (Heist et al. 1995) and bull $C$. leucas (Tillett et al. 2012) sharks.

While the present study is consistent with female philopatric behaviour reported for this species, it is the first to have detected population structure in white sharks with biparentally inherited nDNA microsatellite loci. One of 6 microsatellite loci, Iox10, gave an $F_{\mathrm{ST}}$ of $0.01183(\mathrm{p}=0.02499)$ between regions which was significant at 0.05 but not after Bonferroni correction. The biological significance of this result cannot be ruled out given the conservative nature of Bonferroni adjustment (Rice 1989). This population structure finding suggests that it may not be just females that exhibit philopatry, but that male white sharks also tend to return to the same region to mate, echoing recent tracking findings (Domeier \& NasbyLucas 2012). This pattern needs to be confirmed with other genetic markers, as locus-specific effects (e.g. selection on closely linked transcription products) could bias results. However, if selection was operating on this locus, the results may be indicative of adaptive genetic differences between eastern and southwestern populations. Inclusion of locus Iox10, developed specifically for the short-fin mako shark Isurus oxyrinchus and experimentally amplified in white sharks by Schrey \& Heist (2002), demonstrates the value of attempting cross-species amplification of microsatellite loci for related elasmobranch species. The locus was unavailable to Pardini et al. (2001) in their microsatellite analyses, but, if utilised, it may have revealed evidence of male population structure and philopatry between continents.

There was an order of magnitude difference between overall microsatellite $F_{\mathrm{ST}}$ compared to mtDNA
CR $F_{\mathrm{ST}}$, which was larger than theoretical expectations. In the absence of sex-biased dispersal and assuming neutrality, there should only be a 4 -fold difference in the effective population size of mtDNA relative to nuclear markers (Birky et al. 1983, 1989). The difference observed here may have been amplified by sex-biased dispersal, where females are more philopatric than males. Taking a random sample of adult individuals immediately after dispersal and before reproduction, and comparing the nuclearencoded population structure found for each gender, would allow evaluation of gender bias in adult behaviours such as reproductive philopatry or dispersal for feeding. The gender with the highest dispersal should show less pronounced genetic population structure (Goudet et al. 2002, Prugnolle \& de Meeus 2002). However, the low sample size and wide temporal distribution of our samples, combined with a likely high proportion of pre-dispersal juveniles, precluded us from performing this analysis. Further investigation is required to clarify whether the levels of philopatry differ between genders in this species. Founder events also have the potential to disrupt the theoretical ratio between the magnitude of $F_{\mathrm{ST}}$ estimated from nuclear and mtDNA markers. The presence of WIOL mtDNA haplotypes on the eastern coast of Australia suggests that founder events may play a role in white shark population dynamics, and the relative importance of this should be factored into future studies of genetic population structure in this species.

\section{Concordance with tracking research}

The observed genetic population structure of white sharks in Australia is broadly concordant with the tracking research of Bruce \& Bradford (2012), which showed cyclic movements of juvenile white sharks $(175$ to $260 \mathrm{~cm})$ between fixed locations along the eastern Australian coast. These authors found the degree of juvenile site fidelity to be high and constant over several years, consistent with the nursery definition of Heupel et al. (2007). Furthermore, although juvenile white sharks have been tracked to New Zealand, indicating a capacity for wide-ranging eastward dispersal, none have been tracked moving west via Tasmania and Bass Strait into southwestern Australian waters (Fig. 1) (Bruce et al. 2006, Bruce \& Bradford 2012). These tracking results identify discrete east coast seasonal nursery areas and show constrained movement around the Australian continent, supporting our genetic population structure 
findings of restricted gene flow between the eastern and southwestern regions. Finding mtDNA population structure between Queensland and New South Wales along the east coast of Australia was surprising due to their close geographical proximity, but may indicate population structure linked to unidentified Queensland nursery locations. Fine-scale tracking data from juveniles along the Queensland coast could be analysed to test this hypothesis. Satellite and photo-identification tracking of white sharks in the northwestern Pacific shows repeated male site fidelity to aggregation sites in the region (Domeier \& Nasby-Lucas 2007, 2008, 2012, Jorgensen et al. 2010). It is not yet known if these sites are used for breeding, but, if so, this would support the possibility for male philopatric behaviour as indicated by our microsatellite population structure results.

\section{Transoceanic dispersal events}

The presence of a group of WIOL haplotypes along the Australian east coast in the Pacific Ocean was unexpected. Transoceanic mtDNA genetic homogeneity would be expected if gene flow were occurring on a regular and extended basis. Instead, strong mtDNA heterogeneity is observed between transoceanic populations (Pardini et al. 2001, Jorgensen et al. 2010), indicating long-term genetic isolation, despite the ability of white sharks to travel the distance. Pardini et al. (2001) found one instance of a $350 \mathrm{~cm}$ male white shark (WIOL Haplotype 21; Fig. 2; GenBank Accession No. AY026211) captured in Tasmania whose mtDNA haplotype clustered with the clade of WIO sharks sampled in South African waters, reinforcing the author's male-biased dispersal hypothesis. Here, we found 5 juvenile WIOL sharks all smaller than $250 \mathrm{~cm}$ (4 female, 1 male) on the eastern Australian coast. Two non-mutually exclusive explanations are possible: (1) extant transoceanic dispersal or migration, such as a pulse of juvenile immigration from the western Indian Ocean or occasional pupping but not recruitment of WIOL females in Australia or (2) transoceanic immigration in the past leading to the establishment of a maternally related WIOL family along Australia's eastern coast. Bruce \& Bradford (2012) tracked a $210 \mathrm{~cm}$ juvenile that moved from eastern Australia to New Zealand, indicating that small juvenile white sharks can be highly vagile. A larger sub-adult female $(380 \mathrm{~cm})$ was also tracked in a return excursion across the Indian Ocean between South Africa and Western Australia by Bonfil et al. (2005), indicating that long-distance transoceanic dispersal in subadult sharks is possible. WIO females may occasionally pup in Australian waters, which could be a manifestation of low levels of female straying, as proposed for philopatric blacktip sharks (Hueter et al. 2005), a behaviour which could assist philopatric species to colonise new territory. A substantial proportion $(9 \%)$ of the east coast samples comprised WIOL sharks, supporting the conjecture that they represent a group with recent WIO ancestry that are resident along the eastern Australian coast. A recently observed similarity between Australian and Mediterranean white shark mtDNA haplotypes was attributed to a past (i.e. during the Pleistocene) navigational error of Indo-Pacific sharks (Gubili et al. 2010). Once arrived, philopatric behaviour may have promoted the establishment of a Mediterranean population. A similar scenario could have founded a WIOL family on the Australian coastline.

The presence of haplotypes initially sampled in New Zealand by others (Pardini et al. 2001) (composed of 4 males, 1 female and 1 shark of unknown gender, all $\geq 210 \mathrm{~cm}$ ) in eastern and southwestern Australian waters is consistent with electronic tracking evidence demonstrating movements of juvenile sharks from Australia to New Zealand (Bruce et al. 2006, Bruce \& Bradford 2012) and vice versa (Francis et al. 2012). However, given the potential for philopatric reproductive behaviour and restricted gene flow, further research is needed to test for white shark genetic population structure between Australia and New Zealand.

\section{Historic effective population size}

Our estimates of $H N_{\mathrm{e}}$ indicate that a substantial ancestral effective population of white sharks (midrange estimate of $\sim 30000$ ) existed for 1000 s of generations. The number of generations over which the $H N_{\mathrm{e}}$ is averaged is approximately $4 H N_{\mathrm{e}}$ (Hare et al. 2011), which, for our samples, is between 11000 and 1073000 generations (for mutation rates of $10^{-3}$ and $10^{-5}$, respectively), equating to $236000-23.6$ million yr (rounded to 1000s), assuming a 22 yr generation time (Dulvy et al. 2008). Few, if any, $H N_{\mathrm{e}}$ estimates have been derived for a shark using a coalescent sampling technique. Whales, however, share many life-history traits with white sharks (long life, slow maturation and low fecundity), and have coalescent $H N_{\mathrm{e}}$ estimates in the $10000 \mathrm{~s}$, similar to our midrange results. Roman \& Palumbi (2003) used the mitochondrial $\mathrm{CR}$ to estimate the female historic 
genetic effective population size of the humpback whale Megaptera novaeangliae, fin whale Balaenoptera physalus and minke whale Balaenoptera acutorostrata, as 34000,51000 and 38000 , respectively, which they translated to census sizes of 240000 , 360000 and 265000.

Coalescent genealogy sampling methods are generally regarded as preferable due to their ability to account for migration as well as genealogical ambiguity (Kuhner 2009); however, white shark migration was not included in our coalescent model. Nevertheless, historic estimates of effective sizes encompass many 1000s of generations of mutation and genetic drift since the most recent common ancestor of all the lineages (represented by the allele set), and should be treated with caution for several reasons. Fluctuations in population size may require many generations to return to a mutation-drift equilibrium and also to reduce $H N_{\mathrm{e}}$ to a harmonic mean (biased towards low values), which probably underestimates the true $H N_{\mathrm{e}}$ (Hare et al. 2011). Another great uncertainty lies in the mutation rates used, which may be highly variable between loci, and are believed to be unusually slow in elasmobranchs (Martin et al. 1992, Martin 1999), possibly introducing orders of magnitude difference between the true $H N_{\mathrm{e}}$ and the derived estimate (Hare et al. 2011). Furthermore, unpredictable migration rates create potential for significant $H N_{\mathrm{e}}$ error. Climate and geographical changes over millennia may have facilitated transoceanic gene flow, thereby inflating genetic diversity, inflating the $H N_{\mathrm{e}}$ size and altering the $H N_{\mathrm{e}}$ scale from a single population to a metapopulation (Portnoy 2010). Thus, our $H N_{\mathrm{e}}$ estimates for white sharks are the first evidence for a substantial historical white shark population, but may have an indeterminate temporal and spatial scale and are potentially unrelated to the $C N_{\mathrm{e}}$ estimates.

\section{Contemporary effective population size}

For an idealized population to retain enough genetic variability and ensure evolutionary potential, its $C N_{\mathrm{e}}$ should be above approximately 500 to 1000 breeding individuals (Franklin 1980, Franklin \& Frankham 1998), although Lande (1995) recommends a $C N_{\mathrm{e}}>5000$. Our white shark $C N_{\mathrm{e}}$ estimate for Australia, approximately 1500 breeding individuals, is above widely accepted $C N_{\mathrm{e}}$ thresholds required to retain evolutionary potential, avoid accumulation of deleterious alleles $\left(C N_{\mathrm{e}}>1000\right)$ and avoid inbreeding depression $\left(C N_{\mathrm{e}}>50\right)$ (Frankham
2002). However, the $C N_{\mathrm{e}}$ estimates for Australia as a whole or the east coast alone may be unpredictably influenced by the population structure found within these groupings. In this respect, the southwestern coast $C N_{\mathrm{e}}$ estimate is considered the most robust as this population of approximately 700 breeding individuals appears substantially genetically isolated, a factor which would contribute to the loss of evolutionary potential and harmful allele accumulation should the actual $C N_{\mathrm{e}}$ be closer to the lower $95 \%$ CI boundaries of our estimates.

It is important to qualify these results, as, although $C N_{\mathrm{e}}$ is a powerful predictor when assumptions are satisfied (non-overlapping generations, random mating, no migration or selection, equal sex ratio and constant population size), deviations from these assumptions of the theoretical Wright-Fisher population may lead to bias or misinterpretation. Biases associated with the linkage disequilibrium (LD) method of $C N_{\mathrm{e}}$ estimation are complex, and the direction of bias is not easily quantified (for summaries see Luikart et al. 2010, Waples \& England 2011). However, the LD method shows robustness to some real-world situations, such as variable reproductive success, uneven sex ratios and selection (Waples 2006, Araki et al. 2007). Fluctuations in population size can influence LD $C N_{\mathrm{e}}$ estimates, and a population increasing from a genetic bottleneck may reduce the $C N_{\mathrm{e}}$ estimate for several generations (Waples 2006). Given the low fecundity of white sharks, it seems unlikely that the population has increased substantially since protection of Australian white sharks in 1997, but this is impossible to quantify without historical population trend data. The extent to which migration affects $C N_{\mathrm{e}}$ estimates is unclear but appears to be low when the migration rate is $<5$ to $10 \%$ and in equilibrium (constant rate of exchange) between genetically distinct populations (Waples \& England 2011). For Australian white sharks, maternal population structure indicates that gene flow is constrained around the continent and severely restricted across oceans; however, the level of male gene flow remains inconclusive despite the slight biparental population structure found here. As neither definitive biparental gene flow nor clear genetic differentiation can be ascertained, it is unclear whether our $C N_{\mathrm{e}}$ estimates represent a discrete population or a broader metapopulation (Luikart et al. 2010).

The application of the LD method to species with overlapping generations has not been investigated in depth, and Luikart et al. (2010) believe it can introduce substantial bias. Waples \& Do (2010) provision- 
ally suggest that the $C N_{\mathrm{e}}$ producing a generation is loosely estimated if the generation length of a species is equivalent to the number of cohorts sampled. White sharks have an estimated generation time of 22 yr (Bruce 2008, Dulvy et al. 2008), and the present study has samples spanning $21 \mathrm{yr}$, which theoretically approximates this requirement. In reality, the high proportion of juveniles makes it unlikely that so many discrete cohorts could have been sampled here, making the impact of overlapping generations impossible to quantify.

To better resolve transoceanic gene flow and the effect of overlapping generations, thereby testing the validity of our $C N_{\mathrm{e}}$ estimates, future studies will require larger sample sizes (200 or greater) taken from clearly defined cohorts and analysed using a more extensive nDNA loci set ( $>10$ loci) (Tallmon et al. 2010, Waples \& Do 2010).

Obtaining a population census size $\left(N_{\mathrm{C}}\right)$ for comparison to $C N_{\mathrm{e}}$ gives substantially more insight into the status of the study species (Luikart et al. 2010), but proved unfeasible for the present study. Sampling and tracking elusive white sharks is time-consuming and hazardous, which restricts the amount of currently available data. The only substantial longterm records of Australian white shark numbers are the shark capture logs from bather protection programs. Unfortunately, many changes over the years in the technology used, beaches monitored and information recorded (Reid \& Krogh 1992, Dudley \& Simpfendorfer 2006, Green et al. 2009) have rendered population estimations from this source highly problematic (Walker 1998), and may be further confounded by philopatric behaviour that can expose these data to a localized stock depletion effect (Hueter et al. 2005).

\section{Conservation implications}

Establishing the extent to which populations are genetically subdivided allows their identification as potentially demographically independent conservation management units (MUs), which may require tailored conservation strategies (Palsbøll et al. 2007). Our findings of white shark population structure in Australia imply that migration rates are low between the eastern and southwestern regions $(<10$ sharks generation $^{-1}$ ), and, consequently, these groups are genetically isolated from each other to a substantial degree. As a precaution, it would be advisable to consider these populations as distinct MUs until their genetic diversity, population structure and size can be better resolved by a targeted rather than opportunistic white shark genetic study. Additionally, the levels of white shark migration between oceans must be established with higher statistical power before gene flow can be rejected and each ocean basin population definitively identified as separate management units.

The finding of genetically separate populations with recurrent habitat utilization for reproduction is of direct relevance to conservation management strategies for white sharks in Australia. The Australian government's white shark recovery plan (Environment Australia 2002, 2008, 2010) prescribes identification of critical white shark habitat, population size and 'genetic status' as key aims. The present study contributes to these aims by highlighting the extent of female white shark population structure, the likelihood of reproductive philopatry and by adding support to tracking research suggesting existence of separate nursery areas which appear to be important juvenile habitats (Bruce \& Bradford 2012). Our study presents the first contemporary effective population size estimates and genetic health characterisation of the white shark. Our $C N_{\mathrm{e}}$ estimates have wide confidence intervals and are preliminary due to low numbers of genetic markers and samples, so they must be interpreted judiciously. However, the data presented here will be valuable for comparisons with future studies when the genetic health of white sharks in Australian waters is further investigated.

\section{CONCLUSIONS}

Our genetic analysis of white sharks suggests population subdivision at a fine spatial scale and behavioural dynamics which were not anticipated. We detected genetic structure in the population between the eastern and southwestern coasts of Australia using both mitochondrial and microsatellite markers. The absence of substantial historical geographical barriers between the 2 regions and the high vagility of juvenile and adult white sharks suggest a behavioural reason for the restricted gene flow. This population differentiation may be the result of reproductive philopatry, whereby sharks return to the same general location for breeding and parturition over many generations. Genetic population structure seen in biparentally inherited loci suggests that males also exhibit reproductive philopatry and may not be panmictic on a continental or a global scale. Furthermore, detecting population structure between groups of immature sharks concords with tracking evidence 
showing that juveniles inhabit nursery areas for extended periods prior to dispersal, consistent with nursery-area philopatry. We also discovered a group of white sharks, more similar in mtDNA haplotype to western Indian Ocean white sharks, present in east coast Australian waters, and sharks with haplotypes first identified from New Zealand-caught sharks present along both the southwestern and eastern coasts of Australia, indicating possible transoceanic and trans-Tasman Sea dispersal or migration events. We have also established a sizable estimate of historic effective population size and made the first initial estimates of current Australian white shark effective population size, which appear to be low and may suggest that populations could risk deleterious genetic consequences. Populations of this species in Australia appear to be more complicated and fragile than previously supposed, demanding further research to ensure conservation success.

Acknowledgements. White shark genotypes can be found at http://www2.dpi.qld.gov.au/extra/era/index.html. This work was supported by the Australian Research Council Centre of Excellence for Coral Reef Studies grant to J. M. Pandolfi. Many thanks to D. Broderick, M. Macbeth, J. Morgan and R. Street, for their guidance and knowledge. Thanks also to M. Bennett, R. Bradford, L. Marshall, N. Otway and J. Werry for information and shark samples. V. Peddemors and R. McAuley have also been instrumental in supplying samples. Thanks to A. Kanani for laboratory and writing assistance. Thanks to R. Waples who provided advice on the estimation of $C N_{\mathrm{e}}$, and P. E. Jorde for providing useful comments on an earlier draft. Four anonymous reviewers provided useful feedback for which we are grateful.

\section{LITERATURE CITED}

Alter SE, Rynes E, Palumbi SR (2007) DNA evidence for historic population size and past ecosystem impacts of gray whales. Proc Natl Acad Sci USA 104:15162-15167

> Anderson SD, Chapple TK, Jorgensen SJ, Klimley AP, Block BA (2011) Long-term individual identification and site fidelity of white sharks, Carcharodon carcharias, off California using dorsal fins. Mar Biol 158:1233-1237

- Araki H, Waples RS, Blouin MS (2007) A potential bias in the temporal method for estimating $N_{\mathrm{e}}$ in admixed populations under natural selection. Mol Ecol 16:2261-2271

Bagley MJ, Lindquist DG, Geller JB (1999) Microsatellite variation, effective population size, and population genetic structure of vermilion snapper, Rhomboplites aurorubens, off the southeastern USA. Mar Biol 134:609-620

Baum JK, Myers RA, Kehler DG, Worm B, Harley SJ, Doherty PA (2003) Collapse and conservation of shark populations in the Northwest Atlantic. Science 299: 389-392

Beerli P (2008) Migrate Version 3.0-A maximum likelihood and Bayesian estimator of gene flow using the coalescent. Available at: http://popgen.sc.fsu.edu/Migrate/
Migrate-n.html (accessed on 17 August 2011)

Birky CW, Maruyama T, Fuerst P (1983) An approach to population and evolutionary genetic theory for genes in mitochondria and chloroplasts, and some results. Genetics 103:513-527

Birky CW Jr, Fuerst P, Maruyama T (1989) Organelle gene diversity under migration, mutation, and drift: equilibrium expectations, approach to equilibrium, effects of heteroplasmic cells, and comparison to nuclear genes. Genetics 121:613-627

Bonfil R, Meyer M, Scholl MC, Johnson R and others (2005) Transoceanic migration, spatial dynamics, and population linkages of white sharks. Science 310:100-103

Boustany AM, Davis SF, Pyle P, Anderson SD, Le Boeuf BJ, Block BA (2002) Satellite tagging - Expanded niche for white sharks. Nature 415:35-36

Boustany AM, Reeb CA, Block BA (2008) Mitochondrial DNA and electronic tracking reveal population structure of Atlantic bluefin tuna (Thunnus thynnus). Mar Biol 156:13-24

Bruce BD (2008) The biology and ecology of the white shark, Carcharodon carcharias. In: Camhi MD, Pikitch EK, Babcock EA (eds) Sharks of the open ocean: biology, fisheries and conservation. Blackwell Scientific, Oxford, p 69-81

Bruce BD, Bradford RW (2012) Habitat use and spatial dynamics of juvenile white sharks, Carcharodon carcharias, in eastern Australia. In: Domeier ML (ed) Global perspectives on the biology and life history of the great white shark. CRC Press, Boca Raton, FL, p 225-253

Bruce BD, Stevens JD, Malcolm H (2006) Movements and swimming behaviour of white sharks (Carcharodon carcharias) in Australian waters. Mar Biol 150:161-172

> Castro ALF, Stewart BS, Wilson SG, Hueter RE and others (2007) Population genetic structure of Earth's largest fish, the whale shark (Rhincodon typus). Mol Ecol 16: 5183-5192

Clement M, Posada D, Crandall KA (2000) TCS: a computer program to estimate gene genealogies. Mol Ecol 9: 1657-1659

Domeier ML, Nasby-Lucas N (2007) Annual re-sightings of photographically identified white sharks (Carcharodon carcharias) at an eastern Pacific aggregation site (Guadalupe Island, Mexico). Mar Biol 150:977-984

> Domeier ML, Nasby-Lucas N (2008) Migration patterns of white sharks Carcharodon carcharias tagged at Guadalupe Island, Mexico, and identification of an eastern Pacific shared offshore foraging area. Mar Ecol Prog Ser 370:221-237

Domeier M, Nasby-Lucas N (2012) Sex-specific migration patterns and sexual segregation of adult white sharks, Carcharodon carcharias, in the northeastern Pacific. In: Domeier ML (ed) Global perspectives on the biology and life history of the great white shark. CRC Press, Boca Raton, FL, p 133-146

Dudley SFJ, Simpfendorfer CA (2006) Population status of 14 shark species caught in the protective gillnets off KwaZulu-Natal beaches, South Africa, 1978-2003. Mar Freshw Res 57:225-240

Dulvy NK, Baum JK, Clarke S, Compagno LJV and others (2008) You can swim but you can't hide: the global status and conservation of oceanic pelagic sharks and rays. Aquat Conserv 18:459-482

Environment Australia (2002) White shark (Carcharodon carcharias) recovery plan. Available at: www.environment.gov.au/coasts/publications/gwsharkplan/index.html (accessed on 17 August 2011) 
Environment Australia (2008) Review of the white shark recovery plan 2002. Available at: www.environment. gov.au/biodiversity/threatened/publications/recovery/ white-shark.html (accessed on 17 August 2011)

Environment Australia (2010) Draft national recovery plan for the white shark (Carcharodon carcharias). Available at: www.environment.gov.au/biodiversity/threatened/ publications/recovery/white-shark.html (accessed on 17 August 2011)

Excoffier L, Lischer HEL (2010) Arlequin suite Ver 3.5: a new series of programs to perform population genetics analyses under Linux and Windows. Mol Ecol Resour 10: 564-567

Feldheim KA, Gruber SH, Ashley MV (2002) The breeding biology of lemon sharks at a tropical nursery lagoon. Proc R Soc B 269:1655-1661

Francis M, Duffy C, Bonfil R, Manning MJ (2012) The third dimension: vertical habitat use by white sharks, Carcharodon carcharias, in New Zealand and tropical waters of the Southwest Pacific Ocean. In: Domeier ML (ed) Global perspectives on the biology and life history of the great white shark. CRC Press, Boca Raton, FL, p 319-342

Frankham R (2002) Genetically viable populations. In: Ballou JD, Briscoe DA, McInness KH (eds) Introduction to conservation genetics. Cambridge University Press, Cambridge, p 336-359

Frankham R (2005) Genetics and extinction. Biol Conserv 126:131-140

Franklin IR (1980) Evolutionary change in small populations. In: Soule ME, Wilcox BA (eds) Conservation biology: an evolutionary-ecological perspective. Sinauer Associates, Sunderland, MA, p 135-150

> Franklin IR, Frankham R (1998) How large must populations be to retain evolutionary potential? Anim Conserv 1: 69-70

> Goudet J, Perrin N, Waser P (2002) Tests for sex-biased dispersal using bi-parentally inherited genetic markers. Mol Ecol 11:1103-1114

Green M, Ganassin C, Reid D (2009) Report into the NSW shark meshing (bather protection) program. Available at: www.dpi.nsw.gov.au/fisheries/info/sharksmart/meshing (accessed on 17 August 2011)

> Gubili C, Johnson R, Gennari E, Oosthuizen WH and others (2009) Concordance of genetic and fin photo identification in the great white shark, Carcharodon carcharias, off Mossel Bay, South Africa. Mar Biol 156:2199-2207

> Gubili C, Bilgin R, Kalkan E, Karhan SÜ and others (2010) Antipodean white sharks on a Mediterranean walkabout? Historical dispersal leads to genetic discontinuity and an endangered anomalous population. Proc R Soc B 278:1679-1686

Hare MP, Nunney L, Schwartz MK, Ruzzante DE and others (2011) Understanding and estimating effective population size for practical application in marine species management. Conserv Biol 25:438-449

> Heist EJ, Graves JE, Musick JA (1995) Population genetics of the sandbar shark (Carcharhinus plumbeus) in the Gulf of Mexico and mid-Atlantic bight. Copeia 1995: 555-562

> Heupel MR, Carlson JK, Simpfendorfer CA (2007) Shark nursery areas: concepts, definition, characterization and assumptions. Mar Ecol Prog Ser 337:287-297

> Hill WG (1981) Estimation of effective population size from data on linkage disequilibrium. Genet Res 38:209-216

> Hoarau G, Boon E, Jongma DN, Ferber S and others (2005)
Low effective population size and evidence for inbreeding in an overexploited flatfish, plaice (Pleuronectes platessa L.). Proc R Soc B 272:497-503

Hueter RE, Heupel MR, Heist EJ, Keeney DB (2005) Evidence of philopatry in sharks and implications for the management of shark fisheries. J Northwest Atl Fish Sci 35:239-247

Jorgensen SJ, Reeb CA, Chapple TK, Anderson S and others (2010) Philopatry and migration of Pacific white sharks. Proc R Soc B 277:679-688

Keeney DB, Heupel MR, Hueter RE, Heist EJ (2005) Microsatellite and mitochondrial DNA analyses of the genetic structure of blacktip shark (Carcharhinus limbatus) nurseries in the northwestern Atlantic, Gulf of Mexico, and Caribbean Sea. Mol Ecol 14:1911-1923

Kuhner MK (2009) Coalescent genealogy samplers: windows into population history. Trends Ecol Evol 24:86-93

Lande R (1995) Mutation and conservation. Conserv Biol 9: 782-791

Luikart G, Ryman N, Tallmon DA, Schwartz MK, Allendorf FW (2010) Estimation of census and effective population sizes: the increasing usefulness of DNA-based approaches. Conserv Genet 11:355-373

Macbeth GM, Broderick D, Ovenden JR, Buckworth RC (2011) Likelihood-based genetic mark-recapture estimates when genotype samples are incomplete and contain typing errors. Theor Popul Biol 80:185-196

> Martin AP (1999) Substitution rates of organelle and nuclear genes in sharks: implicating metabolic rate (again). Mol Biol Evol 16:996-1002

Martin AP, Naylor GJP, Palumbi SR (1992) Rates of mitochondrial DNA evolution in sharks are slow compared with mammals. Nature 357:153-155

Mills LS, Allendorf FW (1996) The one-migrant-per-generation rule in conservation and management. Conserv Biol 10:1509-1518

- Narum SR, Stephenson JJ, Campbell MR (2007) Genetic variation and structure of Chinook salmon life history types in the Snake River. Trans Am Fish Soc 136: 1252-1262

> Palsbøll PJ, Bérubé M, Allendorf FW (2007) Identification of management units using population genetic data. Trends Ecol Evol 22:11-16

Palstra FP, Ruzzante DE (2008) Genetic estimates of contemporary effective population size: What can they tell us about the importance of genetic stochasticity for wild population persistence? Mol Ecol 17:3428-3447

> Pardini AT, Jones CS, Scholl MC, Noble LR (2000) Isolation and characterization of dinucleotide microsatellite loci in the great white shark, Carcharodon carcharias. Mol Ecol 9:1176-1178

Pardini AT, Jones CS, Noble LR, Kreiser B and others (2001) Sex-biased dispersal of great white sharks. Nature 412: 139-140

> Peakall R, Smouse PE (2006) GENALEX 6: genetic analysis in Excel. Population genetic software for teaching and research. Mol Ecol Notes 6:288-295

> Pepperell JG (1992) Trends in the distribution, species composition and size of sharks caught by gamefish anglers off southeastern Australia, 1961-90. Aust J Mar Freshwater Res 43:213-225

Portnoy D (2010) Molecular insights into elasmobranch reproductive behavior for conservation and management. In: Carrier JC, Musick JA, Heithaus MR (eds) Sharks and their relatives. II. Biodiversity, adaptive 
physiology, and conservation. CRC Press, Boca Raton, FL, p 435-457

Portnoy DS, McDowell JR, McCandless CT, Musick JA, Graves JE (2009) Effective size closely approximates the census size in the heavily exploited western Atlantic population of the sandbar shark, Carcharhinus plumbeus. Conserv Genet 10:1697-1705

- Prugnolle F, de Meeus T (2002) Inferring sex-biased dispersal from population genetic tools: a review. Heredity 88 : 161-165

Ralls K, Ballou J, Brownell RL (1983) Genetic diversity in California sea otters - theoretical considerations and management implications. Biol Conserv 25:209-232

Reed DH, Frankham R (2003) Correlation between fitness and genetic diversity. Conserv Biol 17:230-237

Reid D, Krogh M (1992) Assessment of catches from protective shark meshing off NSW beaches between 1950 and 1990. Mar Freshw Res 43:283-296

Riccioni G, Landi M, Ferrara G, Milano I and others (2010) Spatio-temporal population structuring and genetic diversity retention in depleted Atlantic bluefin tuna of the Mediterranean Sea. Proc Natl Acad Sci USA 107: 2102-2107

Rice WR (1989) Analyzing tables of statistical tests. Evolution 43:223-225

Roman J, Palumbi SR (2003) Whales before whaling in the North Atlantic. Science 301:508-510

Rousset F (2008) GENEPOP ‘007: a complete re-implementation of the GENEPOP software for Windows and Linux. Mol Ecol Resour 8:103-106

Saitou N, Nei M (1987) The neighbor-joining method: a new method for reconstructing phylogenetic trees. Mol Biol Evol 4:406-425

Schrey AW, Heist EJ (2002) Microsatellite markers for the shortfin mako and cross-species amplification in lamniformes. Conserv Genet 3:459-461

Schrey AW, Heist EJ (2003) Microsatellite analysis of population structure in the shortfin mako (Isurus oxyrinchus). Can J Fish Aquat Sci 60:670-675

Schultz JK, Feldheim KA, Gruber SH, Ashley MV, McGovern TM, Bowen BW (2008) Global phylogeography and seascape genetics of the lemon sharks (genus Negaprion). Mol Ecol 17:5336-5348

Shelden KEW, DeMaster DP, Rugh DJ, Olson AM (2001) Developing classification criteria under the US Endangered Species Act: bowhead whales as a case study. Conserv Biol 15:1300-1307

Smith SE, Au DW, Show C (1998) Intrinsic rebound potentials of 26 species of Pacific sharks. Mar Freshw Res 49: 663-678

Spieth PT (1974) Gene flow and genetic differentiation.

Editorial responsibility: Philippe Borsa,

Montpellier, France
Genetics 78:961-965

Stevens JD, Bonfil R, Dulvy NK, Walker PA (2000) The effects of fishing on sharks, rays, and chimaeras (chondrichthyans), and the implications for marine ecosystems. ICES J Mar Sci 57:476-494

Sulaiman ZH, Ovenden JR (2010) Population genetic evidence for the east-west division of the narrow-barred Spanish mackerel (Scomberomorus commerson, Perciformes: Teleostei) along Wallace's Line. Biodivers Conserv 19:563-574

Tallmon DA, Gregovich D, Waples RS, Baker CS and others (2010) When are genetic methods useful for estimating contemporary abundance and detecting population trends? Mol Ecol Resour 10:684-692

> Tamura K, Nei M (1993) Estimation of the number of nucleotide substitutions in the control region of mitochondrial DNA in humans and chimpanzees. Mol Biol Evol 10:512-526

Tamura K, Dudley J, Nei M, Kumar S (2007) MEGA4: molecular evolutionary genetics analysis (MEGA) software Version 4.0. Mol Biol Evol 24:1596-1599

> Tillett BJ, Meekan MJ, Field IC, Thorburn DC, Ovenden $\mathrm{J}$ (2012) Evidence for reproductive philopatry in the bull shark Carcharhinus leucas. J Fish Biol 80:2140-2158

> Van Oosterhout C, Hutchinson WF, Wills DPM, Shipley P (2004) MICRO-CHECKER: software for identifying and correcting genotyping errors in microsatellite data. Mol Ecol Notes 4:535-538

Walker TI (1998) Can shark resources be harvested sustainably? A question revisited with a review of shark fisheries. Mar Freshw Res 49:553-572

Waples RS (2006) A bias correction for estimates of effective population size based on linkage disequilibrium at unlinked gene loci. Conserv Genet 7:167-184

> Waples RS, Do C (2008) LDNE: a program for estimating effective population size from data on linkage disequilibrium. Mol Ecol Resour 8:753-756

> Waples RS, Do C (2010) Linkage disequilibrium estimates of contemporary $N_{\mathrm{e}}$ using highly variable genetic markers: a largely untapped resource for applied conservation and evolution. Evol Appl 3:244-262

Waples RS, England PR (2011) Estimating contemporary effective population size on the basis of linkage disequilibrium in the face of migration. Genetics 189:633-644

> Wright S (1931) Evolution in Mendelian populations. Genetics 16:97-159

> Wright S (1950) Genetical structure of populations. Nature 166:247-249

Wright S (1965) The interpretation of population structure by $F$-statistics with special regard to systems of mating. Evolution 19:395-420

Submitted: August 23, 2011; Accepted: February 6, 2012

Proofs received from author(s): May 8, 2012 